Review Article

\title{
Nasal and Sinus Diseases: Common Causes of Upper Airway Cough Syndrome
}

\author{
Niken L. Poerbonegoro, ${ }^{*}$ Nina Irawati, Sonia M. Anjani \\ Department of Otorhinolaryngology-HNS, Faculty of Medicine Universitas Indonesia- \\ dr Cipto Mangunkusumo Hospital, Jakarta \\ *Corresponding author: niken_Ip@yahoo.com \\ Received 6 May 2021; Accepted 19 December 2021 \\ https://doi.org/10.23886/ejki.9.33.243
}

\begin{abstract}
Upper airway cough syndrome (UACS), previously known as post-nasal drip syndrome, is a persistent cough that lasts more than four weeks in children or more than eight weeks in adults, which is associated with nasal and sinus diseases, such as allergic rhinitis (AR), chronic rhinosinusitis (CRS), and adenoid hypertrophy (AH). UACS is one of the major causes of chronic cough. Several theories support the pathophysiology of chronic cough in UACS, namely post-nasal drip, airway inflammation, and sensory neural hypersensitivity theories. Persistent and excessive cough generates a deterioration in patient's quality of life and social interaction. This review summarizes the knowledge on pathophysiology and underlying disease of UACS, aims to help clinicians identify and treat this syndrome.

Keywords: adenoid hypertrophy, allergic rhinitis, chronic cough, chronic rhinosinusitis, upper airway cough syndrome.
\end{abstract}

\section{Penyakit Sinonasal: Penyebab Tersering dari Sindrom Batuk Saluran Napas Atas}

\begin{abstract}
Abstrak
Sindrom batuk saluran napas atas (upper airway cough syndrome/UACS), yang sebelumnya dikenal dengan istilah sindrom postnasal drip, merupakan batuk persisten yang terjadi selama lebih dari 4 minggu pada anak atau lebih dari 8 minggu pada dewasa yang berhubungan dengan penyakit sinonasal, seperti rinitis alergi, rinosinusitis kronis, dan hipertrofi adenoid. UACS merupakan salah satu penyebab tersering dari batuk kronis. Beberapa teori yang mendukung patofisiologi terjadinya batuk kronis pada UACS yakni teori postnasal drip, teori inflamasi saluran napas, dan teori hipersensitivitas saraf sensoris. Batuk yang berat dan persisten dapat menyebabkan penurunan kualitas hidup dan interaksi sosial. Artikel ini merangkum pengetahuan mengenai patofisiologi dan penyakit-penyakit yang mendasari terjadinya UACS, dengan tujuan membantu klinisi untuk dapat mengidentifikasi dan mengobati sindrom ini.
\end{abstract}

Kata kunci: batuk kronis, hipertrofi adenoid, rinitis alergi, rinosinusitis kronis, sindrom batuk saluran napas atas. 


\section{Introduction}

Chronic cough is a persistent cough that occurs more than four weeks in children and more than eight weeks in adults. In 2015, the prevalence of chronic cough in the world reaches $9.6 \% ;^{1}$ most commonly found among Europeans and Americans, due to urbanization and increasing irritant exposure. ${ }^{1}$ In contrast, there were very few reports on the number of chronic cough cases in Asia including Indonesia. Consequently, most physicians give less attention to chronic cough cases that lead to suboptimal daily practice treatment. Persistent and excessive cough deteriorates patients' quality of life and social interaction. ${ }^{2}$ Therefore, basic knowledge on pathophysiology and underlying chronic cough is important to improve a patient's disease management.

There are three major causes of chronic cough: upper airway cough syndrome (UACS), gastroesophageal reflux disease (GERD), and asthma. ${ }^{2}$ UACS, previously known as post-nasal drip syndrome, is a chronic cough associated with nasal and sinus conditions, such as allergic rhinitis (AR), chronic rhinosinusitis (CRS), and adenoid hypertrophy $(\mathrm{AH}) .^{3}$ Those diseases often appear together, although one might precede the others, particularly in children. These findings support the complexity of chronic cough management. ${ }^{3,4}$

\section{Theories of Pathophysiology}

The underlying mechanism of UACS remains unclear. Several theories might explain the pathophysiology of chronic cough related to nasal and sinus diseases, namely post-nasal drip, airway inflammation, and sensory neural hypersensitivity theories. ${ }^{3,5}$

\section{Post-nasal Drip Theory}

Post-nasal drip (PND) is a common finding on nasal and paranasal sinus disease. PND is defined as the drainage of secretions from the nose or paranasal sinuses to the pharynx. The secretion mechanically stimulate cough receptors and afferent nerves in the pharynx, larynx, or lower airway; the stimulus is transmitted to the central nervous system, causing a cough reflex., That theory remains controversial. In the previous study of 108 rhinitis/rhinosinusitis patients, $21 \%$ of patients with post-nasal drip complained of cough and only $8 \%$ of patients with a cough had a postnasal drip. ${ }^{6}$ Those findings shows that cough is uncommon in post-nasal drip cases and cough might not be associated with post-nasal drip.

\section{Airway Inflammation Theory}

UACS can be caused by chronic inflammation on the upper airway, lower airway, or both. Releasing local or systemic inflammatory mediators namely histamine and prostaglandins would stimulate cough receptors releasing local or systemic inflammatory mediators, including histamine and prostaglandins. That would stimulate cough receptors afferent nerves and inducing a cough reflex. ${ }^{3}$ Studies have shown that long-term airway inflammation results in airway structural changes such as increased subbasement membrane thickness, vessel size, and goblet cell hyperplasia which can increase cough sensitivity, lead to chronic cough. ${ }^{7}$

\section{Sensory Neural Hypersensitivity Theory}

The inflammatory mediators released during inflammatory reaction on allergic rhinitis or rhinosinusitis such as histamine or neuropeptides activate trigeminal nerve, the sensory nerve in the nasal mucosa, via transient receptor potential vanilloid-1 (TRPV1) receptors (Figure 1.). The stimulus will follow the trigeminal afferent pathway to the central nervous system, then through the vagal nerve and cause the cough reflex. The pathway that causes cough reflex is known as nasovagal reflex or nasobronchial reflex. ${ }^{3,} 8$ If untreated, chronic inflammation in allergic rhinitis and rhinosinusitis increase the sensory nerve sensitivity to various non-specific stimuli. Cold-dry air, strong odours, and smoke will trigger cough reflex. ${ }^{8}$

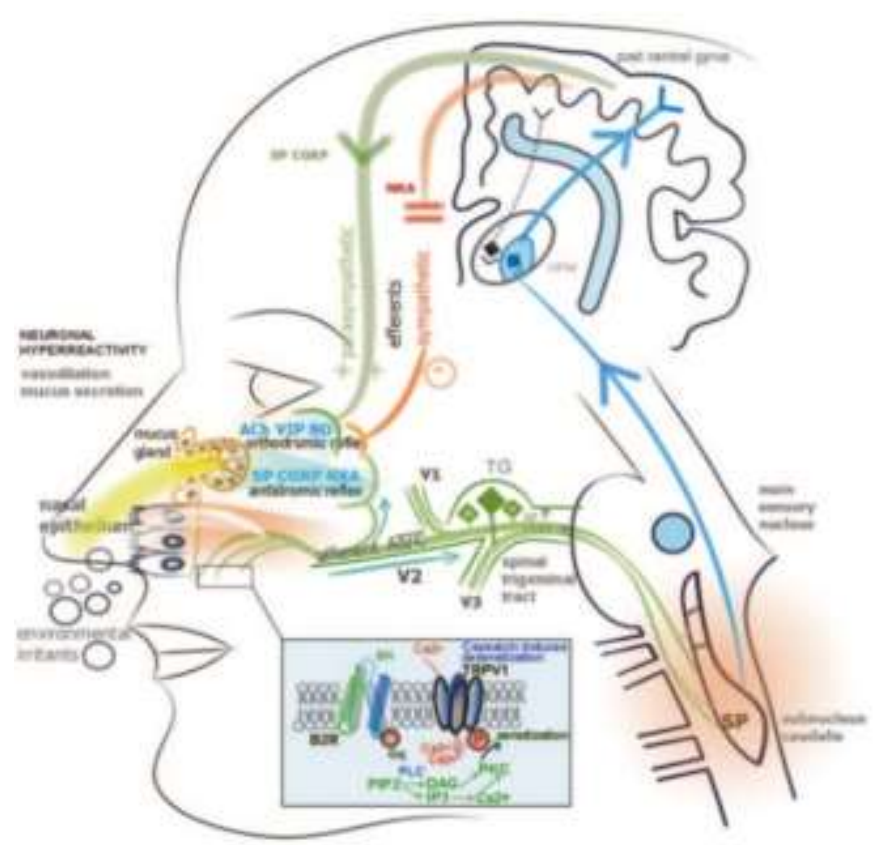

Figure 1. Schematic View of the Neural Hyperreactivity ${ }^{8}$ 


\section{Aetiologies of Upper Airway Cough Syndrome Allergic Rhinitis}

Allergic rhinitis (AR) is an lgE-mediated chronic nasal inflammation characterized by two or more symptoms: sneezing, nasal congestion, nasal itching, or rhinorrhoea. Cough is atypical symptom in $47 \%$ of $A R$ patients. ${ }^{9} A R$ is an allergic disease commonly found in daily practice. The prevalence of $A R$ is $40 \%$ in the adult population while in child population aged $6-7$ years old, the prevalence was up to $14,9 \% .^{10,11}$ In ISAAC study, it was found that $18,6 \%$ experienced $A R$ at the age of $13-14$ years. ${ }^{12}$

One of theAR symptoms is nasal congestion. Upon this condition, the patient tends to breathe through the mouth so that inhaled air would not undergo warming and humidification processes which are essential in maintaining the comfort air temperature and humidity. Cold and dry air will stimulate receptors in the pharynx, inducing cough reflex.
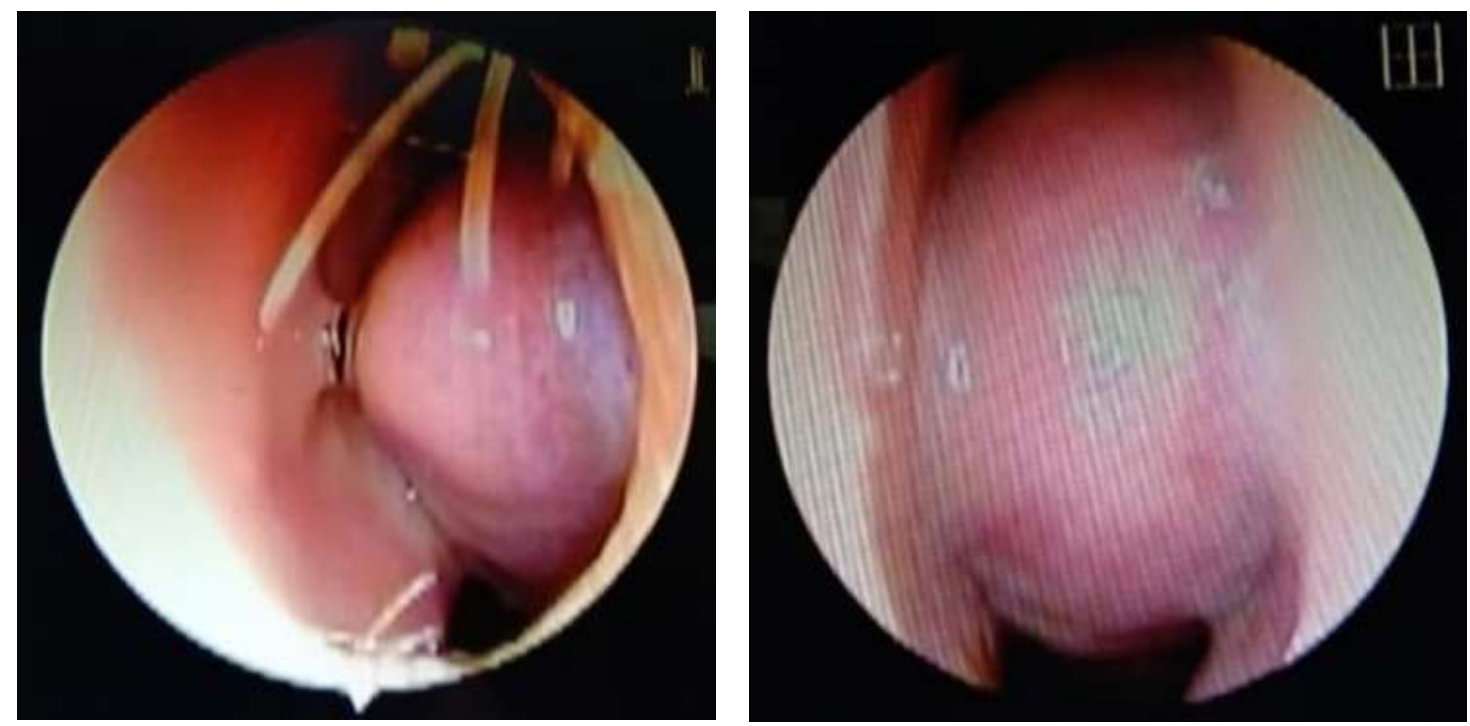

Figure 2. Physical Examination Findings in AR. Narrow nasal cavity, inferior turbinate hypertrophy, serous nasal secretion.

Topical corticosteroids and antihistamines are the drugs of choice for UACS due to AR. If feasible, environmental control to avoid the possible allergen exposure is highly recommended. According to The Allergic Rhinitis and Its Impact on Asthma (ARIA) 2008 Guideline, the treatment for AR patients is based on $A R$ classification. AR is classified into intermittent or persistent based on the frequency and duration of symptoms. It is further classified into mild or moderate-severe based on the severity of symptoms and the presence of impaired quality of life. Topical corticosteroid is the first-line treatment for persistent and moderate-severe AR. New generation antihistamine could be added if symptoms of sneezing, itching, or rhinorrhoea are present and disturbing. If asthma co-exists, adding on leukotriene receptor antagonists (LTRAs) might be considered. The patient's condition should be evaluated in $2-4$ weeks. If there is no improvement, it is important to re-evaluate the diagnosis, comorbidity, and adherence to therapy.
For refractory cases, referral to an ENT specialist is necessary for specific immunotherapy or surgery if indicated. ${ }^{13}$

\section{Chronic Rhinosinusitis}

Based on EPOS 2020, chronic rhinosinusitis (CRS) with or without polyps is defined as the presence of two or more symptoms, one of which should be a nasal obstruction or nasal discharge with \pm facial pain/pressure, \pm reduction or loss of smell in adults, or coughing in children, that last for $\geq$ 12 weeks. ${ }^{14}$ The prevalence of CRS is estimated to be $15 \%$ in the adult population. One study reported that more than $50 \%$ of CRS has comorbidity with AR. ${ }^{15}$ It is varied up to $89 \%$ CRS patients were found to have $\mathrm{AH}$, especially in children. ${ }^{16}$

Nasal endoscopy in CRS patients may show polyp in the middle meatal (Fig. 3a) or mucopurulent discharge (Fig. 3b) draining into the nasopharynx. This finding supports the post-nasal dripping theory as the cause of UACS due to CRS. Definite diagnosis of CRS is using CT Scan, but 
this modality is not routenely recommended to be performed based on EPOS 2020 CRS management guidelines. However, CRS patients should undergo

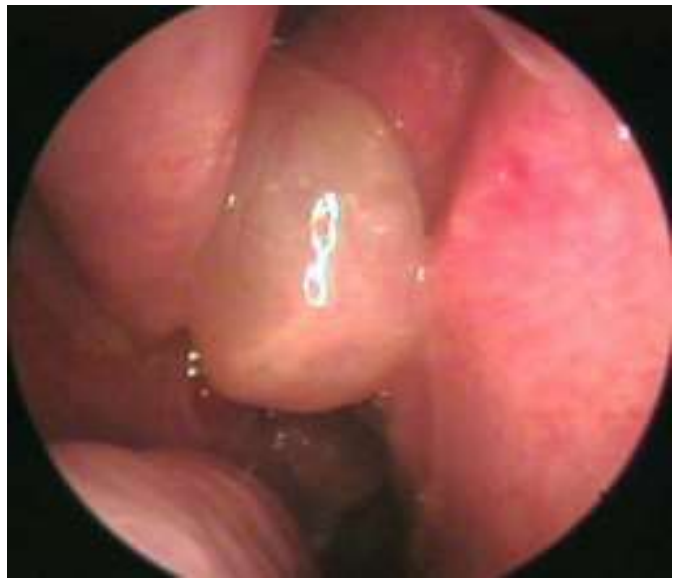

Figure 3. Endoscopic View of CRS a) With a Polyp, B) Without Polyp sinus imaging if there is no improvement after appropriate pharmacological therapy and when surgical management. ${ }^{14}$

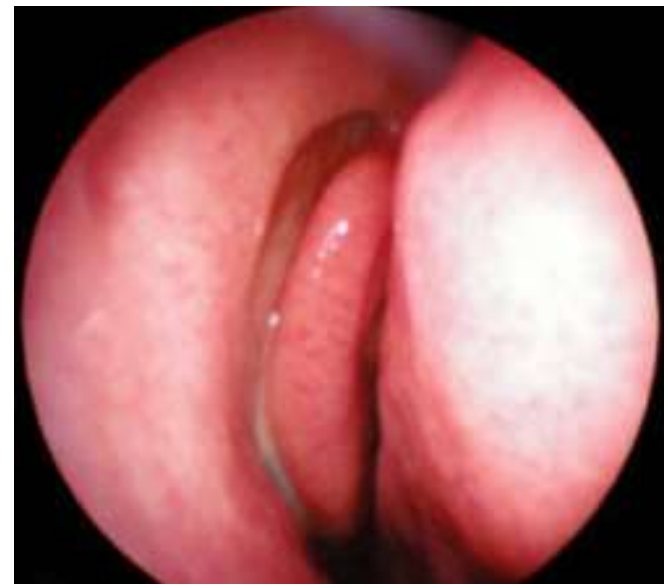

Topical corticosteroid and nasal irrigation with normal saline are the initial treatment of choice in CRS. If there is improvement after four weeks of pharmacological therapy, the treatment can be continued. Referral to an ENT specialist is needed when no significant improvement of symptoms. CRS endotypes should be determined for considering a long-term macrolide antibiotic therapy or surgical management. ${ }^{17}$

\section{Adenoid Hypertrophy}

Adenoid is a part of the waldeyer's ring, classified as mucosa-associated lymphoid tissue (MALT). ${ }^{18}$
Physiologically, adenoid volume increases and reaches its maximum size at the age of 5 - 6 years old and gradually decreases and involutes at the age of 10 . Under normal conditions, the increase of adenoid volume will not cause the symptom. Adenoid's abnormal enlargement (hyperplasia) leads to various symptoms depending on the obstructed structure. ${ }^{19}$ The common symptoms in $\mathrm{AH}$ are nasal obstruction, mouth breathing, chronic cough, snoring, obstructive sleep apnoea (OSA), frequent ear infection, and adenoid facies. ${ }^{20}$ As seen in Fig. 4, more than $70 \%$ of $\mathrm{AH}$ obstructs the choana, nasal posterior, and the eustachian tube.

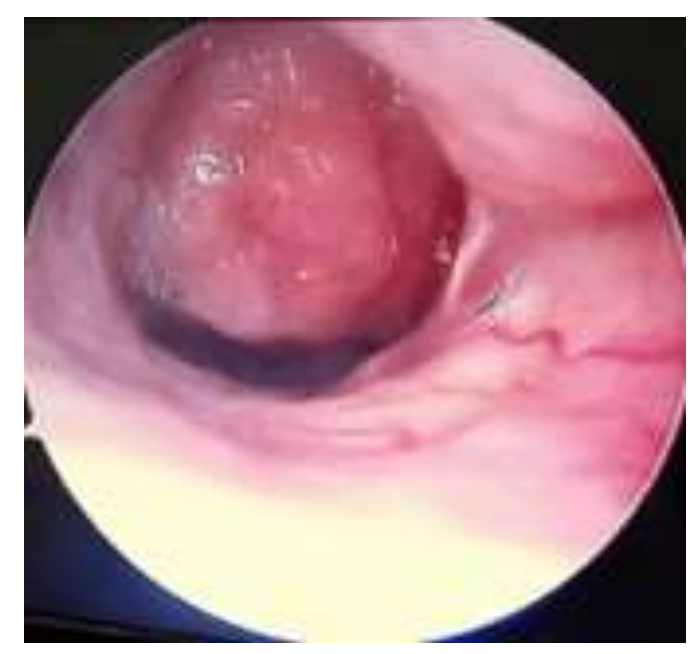

Figure 4. Endoscopic View of Adenoid Hypertrophy 
The prevalence of $\mathrm{AH}$ is estimated $49.7 \%$ of the total population. It is varied $19-58 \%$ at the age of 6 months - 15 years. ${ }^{21}$ One study reported that $30 \%$ of AH patients are found to have AR. ${ }^{22}$ In Cipto Mangunkusumo ENT outpatient clinic, AH patients reached 141 cases in $2013-2014$.

The appropriate management of $\mathrm{AH}$ with the presence of infection (acute bacterial exacerbation) is oral antibiotics. The drug of choice is amoxicillinclavulanate, while clindamycin and azithromycin are considered alternatives for those with penicillin allergies. An intranasal corticosteroid can treat the symptoms of nasal congestion. Surgery management, such as adenoidectomy, should only be considered if the patient has persistent or recurrent symptoms of nasal blockage or infection due to $\mathrm{AH}^{20}$

\section{Treatment for Intractable Cough}

Despite appropriate treatment according to UACS underlying disease, several studies show that first-generation antihistamine may be an alternative therapy for intractable cough. The first-generation antihistamine can control the cough because of its ability to bind with receptors in the central nervous system. Due to the blood-brain barrier penetrating of antihistamine, sedation also has a role in suppressing cough excitability. ${ }^{23}$ In addition, the first-generation antihistamine is known to have anticholinergic properties because of their competitive antagonist to acetylcholine at the neural muscarinic receptor, thus resulting in an antitussive effect. ${ }^{24}$ Gabapentin, one of the neuromodulators, is an option for intractable cough because of neuronal function modulation of upper airway nerve endings (hypersensitivity theory). ${ }^{25}$

\section{Conclusion}

Upper airways evaluation should be performed in chronic cough cases. Recommendations for UACS treatment should be according to its underlying diseases, namely allergic rhinitis, chronic rhinosinusitis, or adenoid hypertrophy. The goal of the treatment is both symptomatic relief and control of underlying causes.

\section{References}

1. Song WJ, Chang YS, Faruqi S, Kim JY, Kang MG, Kim S, et al. The global epidemiology of chronic cough in adults: a systematic review and metaanalysis. Eur Respir J. 2015;45(5):1479-81. doi: 10.1183/09031936.00218714.

2. Michaudet C, Malaty J. Chronic Cough: Evaluation and Management. Am Fam Physician [Internet]. 2017 Nov 1; 96(9):[575-80 pp.]. Available from: https://pubmed.ncbi.nlm.nih.gov/29094873/.
3. Yu L, Xu X, Lv H, Qiu Z. Advances in upper airway cough syndrome. KJMS. 2015;31(5):223-8. doi: 10.1016/j.kjms.2015.01.005.

4. GaoF, GuQL, JiangZD. Upper airwaycough syndrome in 103 children. Chin Med J (Engl). 2019;132(6):6538. doi: $10.1097 / \mathrm{cm} 9.0000000000000118$.

5. Pratter MR. Chronic upper airway cough syndrome secondary to rhinosinus diseases (previously referred to as postnasal drip syndrome): ACCP evidence-based clinical practice guidelines. Chest. 2006;129(1 Suppl):63s-71s. doi: 10.1378/ chest.129.1_suppl.63S.

6. O'Hara J, Jones NS. "Post-nasal drip syndrome": most patients with purulent nasal secretions do not complain of chronic cough. Rhinology. 2006;44(4):270-3. Available from: https://pubmed. ncbi.nlm.nih.gov/17216744/.

7. Lucanska M, Hajtman A, Calkovsky V, Kunc P, Pecova R. Upper Airway Cough Syndrome in Pathogenesis of Chronic Cough. Physiol Res. 2020;69(Suppl 1):S35-s42. doi: 10.33549/physiolres.934400.

8. Singh U, Bernstein J. Intranasal Capsaicin in Management of Nonallergic (Vasomotor) Rhinitis. Progress in drug research Fortschritte der Arzneimittelforschung Progrès des recherches pharmaceutiques. 2014;68:147-70. doi: 10.1007/978-3-0348-0828-6-6.

9. Dykewicz MS, Wallace DV, Amrol DJ, Baroody FM, Bernstein JA, Craig TJ, et al. Rhinitis 2020: A practice parameter update. J Allergy Clin Immunol. 2020;146(4):721-67. doi: 10.1016/j.jaci.2020.07.007.

10. Brożek JL, Bousquet J, Agache I, Agarwal A, Bachert C, Bosnic-Anticevich S, et al. Allergic Rhinitis and its Impact on Asthma (ARIA) guidelines-2016 revision. J Allergy Clin Immunol. 2017;140(4):950-8. doi: 10.1016/j.jaci.2017.03.050.

11. Sultész $M$, Horváth $A$, Molnár $D$, Katona $G$, Mezei $G$, Hirschberg $A$, et al. Prevalence of allergic rhinitis, related comorbidities and risk factors in schoolchildren. Allergy Asthma Clin Immunol. 2020;16(1):98. doi: 10.1186/s13223-020-00495-1.

12. Ellwood P, Asher MI, Beasley R, Clayton TO, Stewart AW. The international study of asthma and allergies in childhood (ISAAC): phase three rationale and methods. Int J Tuberc Lung Dis. 2005;9(1):106. Available from: https://pubmed.ncbi.nlm.nih. gov/15675544/.

13. Bousquet J, Khaltaev N, Cruz AA, Denburg J, Fokkens WJ, Togias $A$, et al. Allergic Rhinitis and its Impact on Asthma (ARIA) 2008 update (in collaboration with the World Health Organization, GA(2)LEN and AllerGen). Allergy. 2008;63 Suppl 86:8-160. doi: 10.1111/j.1398-9995.2007.01620.x.

14. Fokkens WJ, Lund VJ, Hopkins C, Hellings PW, Kern R, Reitsma S, et al. European Position Paper on Rhinosinusitis and Nasal Polyps 2020. Rhinology. 2020;58(Suppl S29):1-464. doi: 10.4193/ Rhin20.600. 
15. Rosati MG, Peters AT. Relationships among allergic rhinitis, asthma, and chronic rhinosinusitis. Am J Rhinol Allergy. 2016;30(1):44-7. doi: 10.2500/ ajra.2016.30.4252.

16. Bulfamante AM, Saibene AM, Felisati G, Rosso C, Pipolo C. Adenoidal Disease and Chronic Rhinosinusitis in Children-ls there a Link? J Clin Med. 2019;8(10). doi: 10.3390/jcm8101528.

17. Fokkens WJ, Lund VJ, Mullol J, Bachert C, Alobid I, Baroody F, et al. European Position Paper on Rhinosinusitis and Nasal Polyps 2012. Rhinol Suppl. 2012;23:3 p preceding table of contents, 1298. Available from: https://pubmed.ncbi.nlm.nih. gov/22764607/.

18. Hellings $P$, Jorissen $M$, Ceuppens JL. The Waldeyer's ring. Acta Otorhinolaryngol Belg. 2000;54(3):237-

41. Available from: https://pubmed.ncbi.nlm.nih. gov/11082757/.

19. Vilella B, Vilella O, Koch H. Growth of the nasopharynx and adenoidal development in Brazilian subjects. Brazilian oral research. 2006;20:70-5. doi: 10.1590/ S1806-83242006000100013.

20. Geiger Z GN. Adenoid Hypertrophy. Treasure Island (FL): StatPearls Publishing; 2021 Jan.
21. Pereira L, Monyror J, Almeida FT, Almeida FR, Guerra E, Flores-Mir C, et al. Prevalence of adenoid hypertrophy: A systematic review and meta-analysis. Sleep Med Rev. 2018;38:101-12. doi: 10.1016/j. smrv.2017.06.001.

22. Ameli F, Brocchetti F, Tosca MA, Signori A, Ciprandi G. Adenoidal hypertrophy and allergic rhinitis: is there an inverse relationship? Am J Rhinol Allergy. 2013;27(1):e5-10. doi: 10.2500/ajra.2013.27.3854.

23. Bolser DC. Older-generation antihistamines and cough due to upper airway cough syndrome (UACS): efficacy and mechanism. Lung. 2008;186 Suppl 1(Suppl 1):S74-7. doi: 10.1007/s00408-007-9033-y.

24. Dicpinigaitis PV, Gayle YE. Effect of the secondgeneration antihistamine, fexofenadine, on cough reflex sensitivity and pulmonary function. $\mathrm{Br} \mathrm{J}$ Clin Pharmacol. 2003;56(5):501-4. doi: 10.1046/j.13652125.2003.01902.x.

25. Weinberger $M$, Hurvitz $M$. Diagnosis and management of chronic cough: similarities and differences between children and adults. F1000Res. 2020;9. doi: 10.12688/f1000research.25468.1. 